\title{
DJ Mini and Montreal's Vulgar Dance Music
}

\author{
$\bullet$ Feature Article $\longrightarrow$ \\ DAVID MADDEN \\ CONCORDIA UNIVERSITY (CANADA)
}

\begin{abstract}
This article advances claims about Montreal's electronic dance music scene through mapping the career of one of the key actors who shaped the electroclash scene from the early 2000s onwards-music producer/DJ Mini (née Evelyne Drouin). By way of detailing the career of DJ Mini, this text attempts to add to the queer musical narratives currently emerging from music scene analyses. Counter to the experiences of many women DJs and musicians participating in heterosexual and male-dominated music scenes, Drouin received extensive mentoring and support from various informal queer social networks spread throughout the circuits of the city. Not only did she gain access to a local production network of equipment and skill sharing, Drouin was also given access to spaces where she was able to develop production skills on her own time and at her own pace. DJ Mini's story offers a telling case for the ways in which the politics of access-institutional, social, technological-remain central to the vitality and inclusivity of local music scenes.
\end{abstract}

KEYWORDS: electroclash; Montreal; DJ Mini; overdose; electronic dance music

David Madden is a soundmaker and Postdoctoral Fellow at Ageing + Communication + Technologies, Concordia University.

Dancecult: Journal of Electronic Dance Music Culture 8(1): 26-45 ISSN 1947-5403 @2016 Dancecult http://dj.dancecult.net http://dx.doi.org/10.12801/1947-5403.2016.08.01.02

desncecult 


\section{INTRODUCTION}

The aim of this article is to advance claims about Montreal's electronic dance music scene through mapping the career of one of the key actors who shaped the electroclash scene from the early 2000s onwards-music producer/DJ Mini (née Evelyne Drouin). Drouin spearheaded Overdose, a weekly electroclash party night at Parking Nightclub in the heart of the city's Gay Village. While running the night for just over seven years (2002-2009), Drouin acted as a DJ, entrepreneur, music producer, cultural broker, promoter, graphic designer and mentor, all of which form the necessary skill set for building and maintaining a successful professional DJ career, whether locally or internationally. By way of detailing the career of DJ Mini, this text attempts to add to the queer musical narratives currently emerging from music scene analyses (Whiteley and Rycenga 2006; Taylor 2008, 2009, 2010; Lawrence 2011), for, as Jodie Taylor argues, the queer subject "is largely forgotten in subcultural and popular music studies" (2012: 153). While negotiating some of the key DIY dilemmas of current independent music culture, such as balancing the entrepreneurial aspects of maintaining a career with the more creative dimensions of music production and performing, Drouin's rather rapid rise to prominence in Montreal's electroclash scene involved working within various informal queer social networks spread throughout the circuits of the city. Counter to the experiences of many women DJs and musicians participating in heterosexual and male-dominated music scenes (see Cohen 1997; Katz 2006; Reitsamer 2011; Gavanas and Reitsamer 2013), Drouin received extensive mentoring and support from bar and record shop owners, in addition to musical training from more experienced DJs and music producers working in Montreal's Gay Village. Not only did she gain access to a local production network of equipment and skill sharing, Drouin was also given access to spaces where she was able to develop production skills on her own time and at her own pace. DJ Mini's story offers a telling case for the ways in which the politics of access-institutional, social, technological-remain central to the vitality and inclusivity of local music scenes.

The second motivation of this article is to challenge certain dominant understandings of electronic dance music through discussing some of the ways in which Montreal operates as a centre of electronic dance music production and consumption, beginning with disco in the 1970s and continuing through the 1980s and 1990s with the development of various local independent music scenes and the emergence of the Gay Village from the early 1980s onwards. Dominant histories of electronic dance music have typically been woven by a "moral geography", says Will Straw, which tend to selectively emphasize the more rigid and mechanical Northern European styles of dance music while rooting out and downplaying its more extravagant and vulgar permutations and expressive possibilities (2008: 114-5). Some of the more vulgar aspects of electronic dance music include the presence of lush orchestral adornments (most commonly connected to late 1970s disco and Eurodisco), the incorporation of female vocal tracks and the mixing of various rock music stylizations. Though the inclusion of female vocal tracks and rock music stylizations are heavily tied to 
the aesthetics of electroclash (Madden 2012), all of the aforementioned vulgar elements of electronic music are tightly connected with Montreal's dance music history. As Straw emphasizes, ever since disco's real or imagined "collapse into vulgarity" and pluralism in the late 1970s, "broad currents within Western dance music have been shaped by the impulse to install rationality and militancy as protective walls" against the possibility of this type of demise; adding: "[T] his has most noticeably been the case within that dance music culture which flirts regularly with rock music" (1993: 171).

\section{Montreal Scene Setting: From Disco to the Indies}

A prominent empirical foundation for this analysis draws from my own experiences within Montreal's electroclash scene and a series of semi-structured interviews I conducted with Drouin in 2011 and 2012. During the interviews, we discussed her personal history with music as a producer, DJ and entrepreneur, among other threads. ${ }^{1}$ The qualitative data collected through this participation in Montreal's electronic music scene(s) in the 2000s is discussed in relation to scholarly literature on music scenes (Straw 1991, 2004; Grenier 1993; Taylor 2012), electronic music (Straw 1993, 2008; Rodgers 2010), Montreal (Remiggi 1998; Stahl 2001; Straw 2005; Stolarick and Florida 2006) and DJ and club culture (Thornton 1995, Fickentscher 2000; Katz 2007). Research into various local music scenes has a long and highly developed history within popular music studies and cultural studies, dating back to at least the late 1980s and early 1990s with the work of Straw (1991), Barry Shank (1994) and, later, Holly Kruse (2003), among others. The concept was initially deployed as a way to move beyond the limitations of the term (musical) community, which implied a degree of uniformity somewhat at odds with the variety of musical practices and expressions emerging within urban centres at the time (Straw 1991: 368). An early foundational definition of scene comes from Straw, who writes: "[A] musical scene ... is that cultural space in which a range of musical practices coexist, interacting with each other within a variety of processes of differentiation, and according to widely varying trajectories of change and cross-fertilization" (1991: 373). The concept of the scene has been particularly useful when mobilized vis-à-vis the ways in which music and a plurality of music-related practices emerge, interact and circulate within particular cities and spaces as well as globally, and it is for these reasons that scene is employed throughout this text in relation to electroclash. Furthermore, as Taylor argues, the notion of the scene is particularly useful when discussing "queer music-oriented collective formations" as the "heterogeneity of scene as an analytical tool allows for multiple points of orientation" (2012: 148). Scene is used to denote various electroclash-related practices throughout Montreal, in addition to smaller, more defined "clusters of social and cultural activity" within the city (Straw 2004: 412). This article is primarily concerned with the ways in which local street-level activities

and institutions (e.g., bars, nightclubs, record stores) produced and sustained the coming together of rock and electro in Montreal in the late 1990s and early 2000s. 
Before moving on to the contributions of Drouin vis-à-vis electroclash, I introduce some important historical developments in Montreal and Quebec that helped set the context for the emergence of the electroclash scene in Montreal at the turn of the millennium. I begin by briefly presenting some broader, current statistics on the Montreal region that may suggest why Montreal continues to develop as a centre for cultural production, art and music, while providing more contextual information for readers who are unfamiliar with the city's cultural makeup. Montreal is one of the twenty-five most populous metropolitan areas in USA and Canada and it is third in terms of population density, after Boston and New York (Stolarick and Florida 2006: 1802). As Stolarick and Florida write, of the twentyfive most populous cities, Montreal has the second-highest percentage of people working in the "super-creative core", which the authors define as those working in the following disciplines: "computers, mathematics, architecture, engineering, life sciences, physical sciences, social sciences, education, training, library, arts, design entertainment, and media" (2006: 1802). Stolarick and Florida argue that the combination of "density and creativeclass employment" create the ideal cultural and economic context for which "innovations generated by the interactions between individuals are more likely to occur" (2006: 1799). One of the key claims that the authors draw from their research on the driving mechanisms of urban economic development is that creative production flourishes and increases in places like Montreal, where there are high numbers of artists and creative workers regularly meeting and engaging with each other (2006: 1801).

Even though Stolarick and Florida's study makes important connections between economic growth and creative workers, their work largely focuses on developments within Montreal from the 2000s onwards-when Montreal's indie music scene began taking shape and receiving international attention thanks to artists such as Godspeed You! Black Emperor and Arcade Fire, and with the establishment of the annual Pop Montreal music festival, which began in 2002. However, it should be noted that many of the important local conditions that enabled the emergence of electroclash materialized much earlier. Dating back to the city's prominent disco scene of the 1970s, Montreal has long been known for an intermixing of nightlife culture and dance music. Entrepreneurs (label owners, DJs, nightclub owners, etc.) capitalized on Montreal's infrastructure of discotheques leftover from the 1960s and the city's heritage and reputation as an epicentre of nighttime entertainment, activity and sin throughout most of the twentieth century (Stahl 2001). In the 1970s, the city emerged as one of the most robust markets for the consumption of disco, whether at nightclubs or through the sales of records and the production of disco, as many local record companies began producing and distributing their music throughout Europe and the Americas in the closing years of the 1970s (Straw 2005: 190). In 1979, at the moment of disco's commercial peak right before the music's international collapse, Billboard magazine deemed Montreal "the second most important disco market on the continent, outside New York" (as cited in Straw 2008: 118).

The rather rapid decline of disco's popularity coincided with the global music industry's first major crisis in thirty years, after a period of unprecedented growth and rationalization 
between 1973 and 1978 (Grenier 1993: 210). In the aftermath of the international crisis, Quebec continued producing large quantities of dance music records, particularly of the Eurodisco and Italo-disco variety, even if many producers and distributors attempted to disguise the origins of their assemblage, fearing that the records might be perceived as coming from the wrong place. Straw writes that Quebec disco labels and performers "cultivated a deliberate vagueness about their identities", which continued the tradition of Canadian and Quebec "cultural commodities to hide (or, at the very least, downplay) their origins, to look as if they came from more credible centres of cultural authority" (2008: 118-9). Between the mid-1970s and the early 1980s, Quebec operated as one of the biggest international centres of production for dance music recordings, and in particular 12-inch vinyl dance singles. Notable local players included the Parapluie group of labels, producer and distributor Vincent De Giorgio, and disco performers such as Karen Silver, Patsy Gallant and Suzy Q (Straw 2008: 118-9).

As Quebec's largely Francophone music industry started producing signs of rejuvenation roughly six years after the crisis (Grenier 1993:212), Montreal's Anglophone and Allophone music-makers remained disproportionately underrepresented within the Quebec industry until the 1990s. However, since this article seems to be setting up a misleading Anglophone/Francophone division within Montreal and Quebec's musical culture at large, I will offer some clarifications before moving forward. ${ }^{2}$ There were many Anglophone and Allophone musicians/artists performing and recording in Quebec in the 1980s and 1990s; however, they were not signed to the Francophone-controlled labels that Grenier (1993) discusses. And, while the music and artists represented by these Franco-indie labels were almost exclusively Francophone, some Anglophone musicians were key players in shaping the sounds that emerged from these Quebec labels in the 1980s and 1990s. The guitarist Rick Haworth, for instance, played on and/or produced many of the popular or hit albums released by the label Audiogram, including the works of Paul Piché, Michel Rivard and Daniel Bélanger. Going further, Grenier speculates that some of the people who had previously worked in the Montreal offices of the Anglo-controlled transnationals and major labels that closed during the crisis of the 1980s ended up working for the new local independent Francophone labels. ${ }^{3}$

On a personal note, when I first moved to Montreal in the late 1990s to pursue undergraduate studies, my impression of the city was that it lacked the necessary infrastructure and smaller performance venues to accommodate the high number of musicians moving to the city annually. Between 1995 and 1999, though there was a very limited selection of legal venues in downtown Montreal that catered to musical groups, many of these establishments maintained pay-to-play policies that inhibited the sustainability and growth of local live music. Pay-to-play arrangements typically involve musicians paying a service fee to a venue in exchange for the chance to perform. Performing musicians in such arrangements also tend to be responsible for all promotional material (e.g., making posters and flyers), hiring a door person to collect cover or admission charges, in addition to guaranteeing the venue a sizable attendance turnout. Furthermore, the venue and the musicians usually agree upon 
a monetary penalty if the minimum number of attendees is not reached. This might explain why a lot of live musical activity in downtown Montreal in the 1990s seemed to take place in semi-legal lofts, warehouses and apartments.

By 2000, more legal venues that did not require musicians to pay for the chance to play began opening up in areas such as Mile End and on or near the upper Main, where, at the time, commercial and residential rental prices were noticeably cheaper than those of the lower Main. ${ }^{4}$ The best-known example of this is the restaurant/music venue Casa del Popolo, which was opened by Montreal musicians Mauro Pezzente and Kiva Stimac in 2000, an establishment that maintains solid bookings of traditional musical ensembles and DJs and a range of other cultural activities, including book launches and poetry readings. Venues like Casa, in addition to many other legal and semi-legal performance spaces, such as lofts and warehouses, started accommodating the city's ever-expanding population of musicians and performers; some of whom, like me, "moved here to study" in the 1990s "and stayed to make music", as Geoff Stahl puts it (2001: 104). Like Stahl, Richard Florida attributes part of this robust sociomusical economy to the relocation by North American musicians to Montreal in the 2000s looking to capitalize on the city's relatively low rental rates-both in terms of living spaces and the availability of rehearsal spaces-and the city's venerable reputation as a centre of cultural production and activity (2011:2). According to Florida's more recent work charting the ongoing geographic changes of the popular music industry, Montreal currently has the third highest "concentration of music business establishments" behind Nashville and Los Angeles, which includes distributors, record companies, recording studios and publishers (2011: 1). Of course, the presence and continued development of the interrelated and pluralistic, yet highly distinct, Anglophone and Francophone music scenes is one of the main reasons why the city has such a high concentration of infrastructure for music-related practices.

\section{Post-Millenial Montreal and Electroclash}

At the turn of the millennium, Montreal's new legal venues and nightclubs also started housing many of the city's electronic dance music party nights, including electroclash events, partly as a consequence of the increasing regulations directed towards raves in the late 1990s. These regulations helped create a temporal shift in consumption, from the afterhours of rave scenes and afterhours clubs, to the hours of the night regulated by alcohol licensing laws. Charity Marsh argues that "the entire raving phenomenon became an object of concern to be researched and studied by municipal authorities, the police force, health care workers, various media, and public intellectuals" in the late 1990s and early 2000s (2006: 416). In Toronto, the increase in rave surveillance and research led to such measures as Bill 73, which "attempted to dissolve rave culture", as Marsh writes, by calling for "a licensing for all venues, building safety code regulations, fire codes, unrestricted access to water, the need for toilets and fresh air, food services, security, paid duty officers, ambulance services, drug and health education, communication with city authorities, a definition of rave, and the periodic review of recommendations" (2006: 424). In her Foucauldian analysis 
of Toronto's rave culture, Marsh is careful to point out, however, that ravers were willing participants in the regulation process and became "ensnared by their own self-disciplining techniques" (2006: 428). Similar regulatory strategies were pursued in Montreal, largely through modifications to existing alcohol licensing laws and the enforcement of municipal fire codes by the Montreal Police Service and local firefighters (Maari 2009). Yet, in spite of these regulations against afterhours parties and raves, Billboard magazine marked Montreal Canada's "hotspot" of EDM culture in 2001 (LeBlanc 2001: 79).

This move away from afterhours partying required a different soundscape as the more epic techno and house musics that DJs had been spinning at raves and afterhours clubs were no longer suitable to the new setting and earlier hours. This transition is best represented musically with Tiga's Mixed Emotions: Montreal Mix Sessions Volume 5, which was released in 2000. Montreal's Tiga spent most of the peak moments of electroclash in the early-to-mid 2000s developing an international career (i.e., primarily outside of Montreal) as a DJ and producer, primarily through the success of a co-produced cover of Corey Hart's "Sunglasses at Night" (2001) - one of the biggest hits of electroclash. Tiga was heavily involved as a pioneering force in Montreal and within the larger electronic dance music scene in Canada and Europe since at least the mid-1990s. The DJ/producer is generally credited with organizing the first rave in Canada (1993's Solstice, which was held in Montreal), in addition to establishing Montreal's first afterhours club (Sona), and DNA Records, the first electronic dance music retail store in Montreal (Girard 2011: 109). In 1998, he also started a record label (Turbo Recordings), which continues to operate within the international circuits of EDM culture.

By the end of the 1990s, Tiga had grown tired and burnt-out from DJing at raves and afterhours clubs throughout the decade and was looking to spin more regularly between 12:00 AM and 3:00 AM. He started DJing at Pub Quartier Latin, a club located a few blocks east of the lower Main, where he introduced dancers to a new set of sounds, including some of the tracks from Mixed Emotions: Montreal Mix Sessions Volume 5. As a DJ, Tiga acts simultaneously as a connoisseur of tastes and as a cultural broker. The Mixed Emotions release pulls together rarities from Tiga's crate-digging practice while attempting to solidify cuts for the emerging late-night dance floor. The double CD is perhaps best understood as representing a transitional moment in electronic dance music, with "Disc 1" (Montreal Mix Sessions Volume 5) devoted to passing sounds and with "Disc 2" (Bonus Electro Funk $C D$ ) comprised of the new proto-electroclash sounds to come. The mix is caught between shifting cycles of EDM, from the big room techno and house Tiga played at raves and afterhours clubs to more electro-oriented dance musics played before 3:00 AM.

Tiga also provides an interesting entry point into the particular personality-driven gender play, cross-dressing and celebrated sexuality that is at the centre of electroclash. Throughout the years when electroclash operated as a dominant form of electronic dance music (2001-2004), Tiga's gender performance was marked by a mix of sexual identities and gender-bending, both in the aesthetic choices he made as a music producer and the imagery and artwork that accompanied his releases. The cover artwork for Mixed Emotions: 
Montreal Mix Sessions Volume 5 pictures a close up photo/illustration of Tiga wearing an androgynous wig and lipstick - referencing a mix of David Bowie's 1970s gender-bending period and Soft Cell's Marc Almond-with the text written in soft pink and purple. The back cover of the CD shows Tiga standing profile in a bathtub with his head cropped out of the photograph, sporting nothing other than a pair of black underwear and a pronounced erection. Most of the press coverage from this period featured a shirtless Tiga looking rather boyish in tight black.

At the turn of the twentieth century, as electroclash party nights started moving to nightclubs and bars and away from afterhours, warehouses and lofts, consumption and performance practices began changing as well. While the genre incorporated many stylistic elements of rock, including its song structural elements and backbeat-driven energy, electroclash club nights, parties and performances imported many of the live practices normally associated with staged rock and pop performances. As Simon Reynolds writes:

This new (nu?) generation have abandoned the very ethos of Ecstasy culture: the principles of egalitarian unity and 'only connect', the notion of shedding your ego in the hypnotic flow of the music and merging with the crowd, and the 'in the mix' aesthetic that treats tracks [as] anonymous components for the DJ's seamless montage. Instead, nu-wave electro-pop songs (known as Electroclash) compete to stand out, through domineering vocals, larger-than-life singers (as opposed to the depersonalised diva-as-raw material approach in most modern dance), witty lyrics, and extravagant amounts of obscenity and trash talk (as cited in Girard 2011: 115).

In the early 2000s, it was not uncommon for electroclash events to be housed at more rockoriented venues or theatres with stages, with audiences starting to face the DJ, producer or performer, who was very often showcased facing the audience on a stage. These parties were also typically marked by the increased consumption of alcohol and cocaine-rather than ecstasy, MDMA and speed, known for their associations with rave culture-a certain gender ambiguity and a corresponding change in dress to skinny ripped jeans, tight $\mathrm{T}$-shirts and heavy makeup, an attire often worn by both men and women.

Previous to these developments, electronic dance music DJs and performers usually took more of an anonymous stance in a live setting, even if they were high profile DJs and/ or producers. In the mid-1990s, rave DJs were typically obscured by flashing lights, with party attendees dispersed in various places on the dance floor, facing and moving in every direction. Although DJs were very often the featured draw of raves and club nights in the 1990 s, with their names prominently displayed on promotional materials, including flyers and posters, party attendees would generally not watch or even face DJs as they performed their sets. For example, this is how Sarah Thornton (1995) contextualizes British dance music clubs in the 1990s and the role of the DJ:

What authenticates contemporary dance cultures is the buzz or energy which results from the interaction of records, DJ and crowd. 'Liveness' is displaced from the stage to the dance floor, from worship of the performer to a veneration of 'atmosphere' or 'vibe'. 
The DJ and dancers share the spotlight as de facto performers; the crowd becomes a self-conscious cultural phenomenon (29)... Though DJs may be musicians, they are rarely performers in the pop sense of the word. In purpose-built clubs, mixing booths tend to be tucked away and DJs unseen. As cultural figures, DJs are known by name rather than face (65).

With the emergence of electroclash in the late 1990s and early 2000s, there was a movement away from the dance music liveness that Thornton discusses. The atmosphere or vibe remained the most important element of an event or party; however, DJs and performers took more of the spotlight as the cult of personality ethos of rock and pop music seemed to arrive alongside the grittier timbres of the backbeats. Electroclash DJs and performers started participating in "the trafficking in performer identity and poetic vision that have marked other musical forms (like rock or soul)", as Straw writes (2008: 129). Around this time, electroclash DJs and performers regularly used microphones for interacting with audiences, perhaps drawing on the live performance practices of hip hop, while the requisite technical precision of seamless cross-fades and beat-matching associated with house and techno DJs was often replaced by rougher mixing techniques. Electroclash sets seemed to play out in more of an identifiable track-to-track fashion, much like a rock or pop show, rather than the throbbing consistency associated with house music, techno and raves in the 1990s.

These emerging production and consumption practices were perhaps most strongly and regularly exhibited in Montreal at DJ Mini's Overdose nights. Much like the "subcultural lore" emerging from Montreal's disco scene in the 1970s (Straw 2005: 191), when electroclash started circulating throughout various nightclubs in the late 1990s and early 2000s, the genre was perceived as having a natural affinity with the city's pre-existing cultural fabric(s). And like disco, electroclash mixed and circulated in Montreal with a certain amount of ease in many social contexts and neighbourhoods, in part because it was not easily categorized as exclusively Francophone or Anglophone, and as neither straight nor gay. In musical terms, this ambiguity is most prominently present in the vocalizations of electroclash. Although much of the lyrical content of the genre is in English, electroclash vocal tracks are often sung with a developed sense of irony and disguised by various digital effects such as a vocoder, which arguably draws listeners and dancers to the materiality of the vocal utterances and phrasing rather than the linguistic content or subject matter of the lyrics (see Weheliye 2002). This connects electroclash to a long history of electronic dance music and, in particular, Eurodisco (and dub), which very regularly employs "highly codified, minimal units of English speech: 'orders, announcements (including self-announcements), greetings, lists, simple reports ('red alert!')' and so on" (Kronengold, quoted in Straw 2008: 129). These discreet units of English are also typically deployed in highly repetitive phrases. For instance, Tiga and Finnish producer Jori "Zyntherius" Hulkkonen's aforementioned "Sunglasses at Night", a cover version of Corey Hart's 1983 release with the same title, leads with an easy-to-follow $\mathrm{ABAB}$ song structure, or verse followed by chorus. Tiga and Zyntherius eliminated the original cut's eight bar pre-chorus employed to set up the 
release of the chorus, and, as a result, the whole track moves back-and-forth between two alternating lyrical refrains, which are sung by Tiga with slight variations: part A, "I wear my sunglasses at night/So I can/So I can/Watch you weave then breath your story lines"; and part B, "Don't masquerade with a guy in shades oh no". By cutting out Hart's pre-chorus, Tiga and Zyntherius' version maintains the same synthesizer progression throughout the track, as Hart's move to the pre-chorus is the only harmonic change in the original song.

\section{DJ MinI AND OVERDOSE}

Aside from the role of the producer, the DJ is perhaps the most masculine professional role in electronic dance music. In scholarly studies of DJ culture over the last twenty-five years, women DJs are most notable for their absence. In Katz's (2007) analysis of battle DJs, for instance, "the vast majority" are men, whether working locally or touring internationally; Fikentscher argues that women DJs number less than ten percent (2000: 33); and Straw (1993) notes that while electronic dance music draws much of its political credibility through its connections to marginalized sexual (and ethnic) communities, "virtually all of the club DJs in the English-speaking world who exercise influence are male" (173). Going further, Straw adds, "there are more women in heavy metal bands than there are female producers or mixers of dance records" (1993: 173). While this article recognizes the importance of detailing the lack of female participation and representation as DJs (and producers) within electronic dance music culture, it should be emphasized that these statistics can be misleading and somewhat arbitrary if the studies that contain them do not analyze the social and cultural factors that produce such numbers. DJ Mini benefitted from a local mixed queer network of people working in various music-related clusters of streetlevel activity-from bars and nightclubs to record stores and domestic studio spaces-who acted as mentors and collaborators throughout her career trajectory. By peering into these smaller local networks of musical activity, it seems that the number of women working with electronic sound changes significantly, especially in comparison to the number of women featured in electronic music magazines or represented on record labels or at major electronic music festivals.

Drouin's move from the periphery to the centre of Montreal's electronic dance music scene in the city's Gay Village at Parking in the 2000s began when her family relocated from Rimouski, QC, to Montreal when she was sixteen. Although she did not have any formal music training or any plans to produce music, Drouin developed an interest in electronic music after attending raves throughout the city. In her own words:

I wasn't really planning to make music in general until I discovered electronic music at raves and then I got really involved with it.... I started going to raves and getting interested in drum ' $n$ ' bass, and I have a feeling it's because of the frequencies, there's so much low-end, the bass is really present and melodic and percussive. ${ }^{5}$

Drouin's pedagogical path to becoming a DJ after her initial experiences at raves started while working at a local club, Bluedog, located on the Main, and known for its queer nights 
in the late 1990s and early 2000s. The manager of the club recognized Drouin's developed interest in DJing and electronic music, and allowed her to use the club's DJ/sound equipment during the day when the club was closed and during the early hours of the night when there were few patrons in attendance. The manager also mentored and trained Drouin as a DJ, in addition to buying the emerging artist some records and a record bag. Mini's development from a beginner DJ with no equipment of her own to a respected working DJ happened relatively quickly (three-to-four years), largely through her commitment to learning various musical techniques, by connecting with networks of other working DJs within the city and through receiving mentoring by more experienced DJs and producers. As Drouin continued to play a variety of nights at Bluedog, DJs who recognized her talent and commitment to the practice started inviting her to DJ at other bars and clubs.

One very experienced professional DJ who spent many years spinning in the Gay Village offered her work in the record shop that he owned, while also teaching her more advanced DJ techniques and introducing her to the DJ circuits of the Village. Before being able to fully support themselves through DJ gigs and/or studio production work, DJs often work in record stores or in musical equipment shops in order to help pay for the heavy capital investment required to become a DJ, as the stores would most likely give their employees a rebate on all in-store purchases, including records and DJ equipment. When Drouin first started DJing nearly twenty years ago, in order to be taken seriously by their peers, aspiring DJs had to develop extensive vinyl collections, both for practice purposes and for gigs/ performances, while also having to acquire two highly specialized vinyl players or turntables, a mixer, headphones and two speakers as necessities of the trade. In the 1990s, before the post-millennial move to primarily using less expensive burned CDs with MP3s in DJ sets, the industry standard for DJing usually included two Technics SL-1200 vinyl players, which could be obtained for approximately $\$ 700$ CAD new, or \$400 CAD used. New 12-inch vinyls cost approximately $\$ 15 \mathrm{CAD}$, and used vinyl records could range from $\$ 3$ to $\$ 5$ CAD. Based on recent conversations with professional DJs in Montreal, a relatively small vinyl collection for a working DJ in the 1990s might have contained about two thousand records; a bigger collection might consist of ten thousand records and beyond.

As stated above, DJ Mini ran Overdose every Thursday for just over seven years at Parking Nightclub (which is no longer in operation). The club was situated on Amherst, just south of Sainte-Catherine Street in the heart of what many consider to be the largest Gay Village in North America (Straw and Tallack 2009: 4). After many of Montreal's gay establishments moved from the city's west-end downtown core in the early 1980s, the Village developed rather quickly in Montreal, following the openings of the bar Au Deux $R$ in February of 1982 and la taverne Normandie, the bar KOX and the nightclub Max in 1983 (Remiggi 1998: 269). By January of 1992, only ten years after the opening of Au Deux $R$, sixty-five out of the one hundred professionals and commercial establishments listed in Fugues (le magazine des gais et lesbiennes du Québec) were concentrated in the neighbourhood, and in particular along Sainte-Catharine (Remiggi 1998: 272). Since the 1990s, the area has continued to develop a strong residential core, in addition to building on its commercial infrastructure of cafés, stores, restaurants, nightclubs and bars. 
Because Drouin's Overdose nights were hosted on Parking's mixed night, there was a highly articulated crossing of genders and sexualities. On mixed nights, gay clubs typically allow heterosexual men and women to enter as long as the door person or bouncer decides that they meet the club's criteria for entrance, whether these involve dress codes or vibes. In contrast, on Friday and Saturday nights at Parking, it was much more difficult for those who identify as straight—or those who were "coded" as straight — to gain admittance to the club. On weekends, gaining entrance to the club was perhaps most difficult for heterosexual women. These types of door policies or gatekeeping mechanisms have historically been put in place in order to maintain a homosocial environment and to protect various gay scenes from acts of homophobia, violence and surveillance. In Montreal, for instance, before moving east in the early 1980s, many of the city's west-end gay establishments along Stanley, Peel and the lower Main were targeted in the 1970s during "une campagne de nettoyage préolympique", as Remiggi writes (1998: 276). Although the "cleaning" was not exclusively directed at Montreal's gay bars, these establishments faced consistent harassment and surveillance by the State throughout much of the 1970s and into the early 1980s.

When Drouin first started to DJ at Parking Nightclub in the early 2000s, the abovementioned mixing at Overdose was not yet present. In its original incarnation, Overdose was much more geared towards gay men and was first established around another DJ (Frigid), who specialized in glam rock and 1990s alternative music. According to Drouin, when she was initially brought in to DJ once per month at Parking, the Thursday night was "originally very, very queer and very glam". I asked Drouin how she eventually started running Overdose and this is how she responded:

I saw that the night was going down, and I thought to myself, this has got to be something else. So why not, why don't I take over. I've worked in bars before, I've done nights, I've done promotion and I know how the system works and the electroclash sound is obviously picking up, so why not push it a little bit further. So I sat down with the owners and I made a business proposal. I basically explained what I would do and the people I would hire.

Building on her previous experiences DJing and working at Bluedog as a bartender, promoter and manager, Mini would go on to perform two full nights per month, which generally meant spinning for four hours at a time. She would also alternate between inviting one international DJ (e.g., Ellen Allien, Richie Hawtin, Felix Da Housecat) and one local guest DJ per month, and thereby beginning the process of acting as a mentor to younger DJs in Montreal. Additionally, Drouin handled all of the bookings, hired much of the bar staff and brought in all of the people for the promotions team, which was initially funded and supported by the proprietors of Parking. Cover charges typically ranged from $\$ 5-\$ 10$ throughout the seven years that Mini ran the night, with anywhere from 350-1200 people coming through the club on any given Thursday.

Drouin also created a mix CD to both pull together and articulate some of the disparate styles that form electroclash-from rock to more techno-inspired dance musics-in 
addition to using the mix as a strategic promotional tool, drawing attention to her new conception of the Overdose night and to her emerging practice as a DJ. Drouin personally burned all copies of the mix CD before distributing them to retail stores, bars and to other DJs throughout downtown Montreal. As she puts it, the mix was a "turning point" for the new "mixed" Overdose night:

I made a mix for people to discover what the sound of the night was going to be. And I got that printed and then distributed in all of the music shops and all of the clothing stores in Montreal. But the CD was originally just for promo, in order to get people involved in my nights.

In this way, a mix CD operates as a branding tool for Drouin and other DJs where the real gains are perhaps better understood in relation to accumulating a certain level of cultural status or capital within a scene, rather than directly gaining economic profits through $\mathrm{CD}$ sales and distribution. Drouin's mix CD was primarily distributed free of charge and functioned as a way to establish a relationship with an audience through a mutually agreed upon set of aesthetic conventions and desires.

Drouin realized that her Overdose night at Parking might be sustainable when the mix was launched and performed as a live DJ set:

The night we did the launch of the CD ... there was water dripping on us and people were going crazy. It was also the turning point, where we actually knew what the sound was, and where we actually got to know the crowd. On the mix CD there was Miss Kittin, Felix Da Housecat, some more underground things, and I think it had Peaches and Gonzales in there as well.

What is perhaps most interesting about the above remarks is the implicit understanding that the success or failure of a recorded mix is largely determined by the response from an audience and the degree to which a DJ is able to maintain an audience for future performances and gigs. Without a strong response from an audience, a mix CD very quickly becomes just another form of discarded ephemera collecting dust on shelves, apartment floors and computer hard drives. Additionally, it is important to point out that for Drouin, ADULT.'s track "Nausea", released by the Detroit label Ersatz Audio in 2000 and included on the mix CD, best represents electroclash, which she describes as "bitchy, square, fully synthetic music with a loud, obnoxious singer over it, singing with a lot of attitude".

Yet, just as Drouin's Overdose emerged as one of the most successful electronic dance music nights in Montreal-in part, because of the heavy rotation of electroclash-a stylistic shift was required to sustain the party. One of the consequences of spinning the latest EDM styles and bringing internationally known DJs to perform at Overdose once every month, is that it puts the night, and Montreal's electroclash scene in general, directly in contact with the shifting cycles of electronic dance music, which is marked by a "rapidity of cyclical change" (Straw 1991: 382). Staying relevant and maintaining a connection vis-à-vis these quickly changing cycles and international dance music culture as a whole requires a local 
party night like Overdose to constantly shift its stylistic focus by incorporating related emerging sounds that are gaining popularity elsewhere. Towards the mid-2000s, electroclash was shortened to electro and the vulgar stylizations were replaced by a more pronounced techno-oriented and instrumental sensibility (Madden 2012).

EDM dance floors began to pushback against the perceived vulgarity of electroclash, as the celebrated glamour, ambiguity, rock orientations and sexuality of the genre were interpreted as stylistic adornments lacking in substance, especially in relation to the more austere historical authenticity of techno. Music journalist Martin Turenne, for instance, reported in Exclaim! ("Canada's music authority") that with electroclash, electronic dance music "has been overtaken by style mavens with little concern for the intricacies of their new found pet sound" (2006). In a similar vein, Brent Luvaas argues that ultimately "the point" of electroclash "is a glamour-obsessed, nostalgic exhibition put on by people more concerned with style than substance" (2006: 173). Progressively, the vocally driven sounds of Peaches' "Fuck the Pain Away" and Miss Kittin \& The Hacker's "Frank Sinatra" played at the turn of the millennium were ousted on dance floors by more techno-leaning instrumental cuts like Alter Ego's "Rocker", which was released in 2004.

This international techno-shift meant that Drouin and the other local DJs performing at Overdose had to incorporate more techno-sounding styles into their sets or risk appearing out of touch with the most current cycles and styles of electronic dance music. As Drouin suggests:

For me, eventually, when electroclash started fading away a little bit and people were kind of tired of hearing that sound, obviously, to keep the night going I moved into a more techno, straight up, four-on-the-floor sound. . . It was a really slow transition. Originally, the first three years were very rock and more queer, and eventually the night moved into more of a Berlin sound, a little bit more tech-house, a little bit more techno and towards the end it was pretty much techno.

However, moving in more of a techno direction in the mid-2000s also caused Overdose to slowly recede into the local electronic dance music scene as one of many techno nights littered throughout various neighbourhoods in the city. As a musical form that was very personality-driven, electroclash allowed a DJ persona to develop in an extravagant fashion that was not so easily available with techno. Not only did Drouin have to reestablish her "signature sound" and look, as she refers to it, the DJ had to further develop skill sets, such as studio production, in order to continue making a living as a performing musical practitioner, given that Overdose slowly started making less and less money. As she emphasizes, "eventually I realized that if I want to survive, I have to make more music. And I decided to make an album". As the night began declining in popularity in the late 2000s, it became clear to Drouin that Overdose would again need to be totally relaunched and reconceptualized to remain operating at Parking. One of the drawbacks of hosting a party night in such a large club, which holds well over five hundred people at any given moment, is that the venue needs to be close to capacity for the night to seem successful and profitable. Unfortunately, 
the moment that Drouin realized that Overdose needed this complete restaging was also the moment that she lost the desire to continue running the night. Being a locally oriented professional DJ keeps one tethered to the circuits of the city, and after seven years of DJing in Montreal and Quebec, Drouin wanted to spend more time traveling and working in the studio as a producer and spend less time booking other DJs for a club night.

By 2007, as Overdose became less and less economically profitable, the infrastructural support needed to run the weekly party night was slowly taken away by the people who owned Parking. Additionally, around this time club owners in Montreal and elsewhere became increasingly weary of investing in street level promotions teams as these networks progressively moved to online social media sites such as Facebook. Mini's initial business plan for the night, which included funding for a promotions team and materials, was no longer maintained as it was most likely a tenuous agreement from the beginning. From 2002-2007, a significant amount of the promotional budget was allotted for designing and printing flyers that would be distributed hand-to-hand by a street team of promoters to other nightclubs, scene actors, schools and retail stores. This form of street level promotional activity was necessary in order to keep any night going, Overdose or otherwise. However, when the budget was cut, the proprietors of Parking expected Drouin and her team to carry out the same labour commitments of the previous five years, including spending five nights per week handing out flyers to nightclub patrons. Once the budget was defunded by Parking it also became much more difficult for Mini to foster relationships with both local and international DJs who might potentially spin at the Thursday night. This meant that Overdose would slowly lose its position in Montreal as a meeting point of local and international EDM culture, and by 2009 , the weekly ended.

\section{CONCLUSION}

For professional DJs working in local or international circuits of electronic dance music, the entrepreneurial aspects of sustaining a career, such as running a label or creating and sustaining a weekly party night, rarely mix well with the more creative aspects of the practice, such as performing and studio production. Maintaining the weekly Overdose night for over seven years and booking all of the DJs and performers, in addition to hiring a promotional team, amongst other duties, requires that "70 percent of your life becomes dedicated to that", as DJ Mini puts it. Luckily for Drouin, and unlike the experiences of many other women DJs working throughout the Western world (see Rodgers 2010), she was able to continually meet and interact with queer networks of other DJs, producers and mentors who were willing to share their knowledge of the craft and their musical equipment in times when she needed some form of support. At the beginning of her career in music, Drouin was helped by the aforementioned amateur DJ and manager of Bluedog. Likewise, a professional DJ assisted her in developing more advanced DJ techniques, while introducing her to DJ possibilities in Montreal's Gay Village and hiring her in the record store that he owned. As she incorporated more studio-based production as part of her practice in the early-to-mid-2000s, Drouin received private sound design lessons for three years from her 
manager's friend, leading up to the release of her first album, Audio Hygiene (2006). As Drouin emphasizes: "after three years, we finally had an album ready. The album was a trialand-error process, with a lot of different genres coming in and out at the same time, because I had the time to experiment".

In the years since Overdose, Mini has made numerous pragmatic decisions in order to continue her professional musical practice as a DJ and producer as she no longer has an ongoing weekly site to rely on. This is not uncommon for DJs and other musical practitioners hoping to establish life-long professional careers in music and creative production. For Drouin, these decisions entail reconsidering the musical genres she incorporates when spinning, the styles of music she produces in the studio, who she collaborates with and the range of gigs she agrees to accept. Since 2009, Mini has expanded her musicing to include more corporate events (e.g., retail store openings, fashion shows and corporate sponsored parties), sound, visual and interface design. She now uses DJ Mini as a brand identity, rather than solely as a DJ moniker, to encompass all of the skills-artistic, educational and entrepreneurial - that she has developed in her nearly twenty-year career. In 2012, Drouin independently released a second full-length album of original tracks entitled Espace Temps, while broadening her mentoring to include educational and musical workshops for kids in Montreal.

Lastly, this article attempts to challenge some of the more dominant understandings of electronic dance music through mapping some of the ways that Montreal operates as a centre of electronic music production and consumption. North American (and Anglo) understandings of dance music tend to follow a selective evolutionary path, with an ongoing fascination with the United States' three urban centres of dance music and their relationship with certain parts of Western Europe, most notably London, Berlin and Paris: Chicago, known as the "birthplace" of house music, in reference to the music played at the club Warehouse in the city during the early 1980s; Detroit, known for its techno associations and the Belleville Three (Juan Atkins, Derrick May and Kevin Saunderson), whose techno dance music sounds launched in the UK on the 1988 Virgin Records compilation, Techno: The Dance Sound of Detroit (Thornton 1995: 74); and New York, where American disco first emerged from David Mancuso's Love Saves the Day party in 1970, the ensuing parties at the Loft in the NoHo district of Manhattan (Lawrence 2003), and nightclubs like the Sanctuary on West 43rd Street (Fickentscher 2000: 26). Because of this Anglo-American centricity, important dance music centres such as Italy, Spain and Quebec, which very likely produced as many disco records as Miami and New York, rarely receive attention in histories of disco and electronic dance music. Interestingly, as Straw contends, disco's "roots in southern France and Italy are just as long as those in the United States, even if the former are seen as less heroically subcultural" (2008: 125). This text argues that part of this omission in the historical record is due to Montreal's continued fascination with the more vulgar aspects of electronic dance music, from the orchestral-infused disco of the late 1970 s and early 1980s to the hypersexual rock stylizations of electroclash at the turn of the millennium and beyond. 


\section{ACKNOWLEDGEMENTS}

The author would like to thank Andra McCartney, Brian Fauteux and Jonathan Sterne for insightful comments on earlier iterations of this article. Many thanks to Dancecult reviewers for such generous feedback.

\section{NOTES}

1 In addition, I attended nearly one party night per month between 2001-2006, Overdose being the event I frequented the most, where I was able to develop numerous ongoing relationships and conversations with party attendees, DJs, promoters and other scene actors.

2 Grenier, drawing directly from the work of Straw (1991), points out that although largely Francophone oriented, Quebec emerged out of the international crisis as a "pluralistic musical space" in the 1980s, "within which a range of musical practices coexist, interacting with each other within a variety of processes of differentiation, and according to widely varying trajectories of changes and cross-fertilization" (Straw, quoted in Grenier 1993: 222).

3 Line Grenier, email to author, 14 September 2012.

4 The Main refers to Montreal's boulevard Saint-Laurent, which has historically operated as a line dividing Montreal's Anglophone population to the west and Francophone population to the east. Martin Allor (1997) writes that over the course of the twentieth century, "the Main has been a kind of liminal zone where the cultural geography of linguistic, ethnic and class differences has intersected with the successive developments of leisure-cultural practices and cultural industry equipment" (44).

5 Evelyne Drouin, interview with the author, 30 December 2011. All further citations are from this interview.

\section{REFERENCES}

Allor, Martin. 1997. "Locating Cultural Activity: The 'Main' as Chronotope and Heterotopia”. Topia 1(1): 42-55.

Cohen, Sara. 1997. "Men Making a Scene: Rock Music and the Production of Gender". In Sexing the Groove: Popular Music and Gender, ed. Sheila Whiteley, 17-36. New York: Routledge.

Farrugia, Rebekah. 2012. Beyond the Dancefloor: Female DJs, Technology and Electronic Dance Music Culture. Chicago: Intellect.

Fikentscher, Kai. 2000. "You Better Work!": Underground Dance Music in New York City. Hanover, NH: Wesleyan University Press.

Florida, Richard. 2011. "The Changing Geography of Pop Music". The Atlantic. 17 February: $<$ http://www.theatlantic.com/entertainment/archive/2011/02/the-changing-geography-ofpop-music/71341/> (accessed 26 February 2015). 
Gavanas, Anna and Rosa Reitsamer. 2013. "DJ Technologies, Social Networks and Gendered Trajectories in European DJ Cultures". In DJ Culture in the Mix: Power, Technology, and Social Change in Electronic Dance Music, eds. Bernardo Alexander Attias, Anna Gavanas and Hillegonda C. Reitveld, 51-77. New York and London: Bloomsbury Academic.

Girard, Stéphane. 2011. "(Un)originality, Hypertextuality and Identity in Tiga's 'Sunglasses at Night'”. Popular Music 30(1): 105-25. <https://doi.org/10.1017/s0261143010000681>.

Grenier, Line. 1993. "The Aftermath of a Crisis: Quebec Music Industries in the 1980s”. Popular Music 12(3): 209-27. <https://doi.org/10.1017/s0261143000005687>.

Katz, Mark. 2006. “Men, Women, and Turntables: Gender and the DJ Battle.” Musical Quarterly 89(4): 580-99. <https://doi.org/10.1093/musqtl/gdm007>.

Kruse, Holly. 2003. Site and Sound: Understanding Independent Music Scenes. New York: Peter Lang.

Lawrence, Tim. 2004. Love Saves the Day: A History of American Dance Music Culture, 19701979. Durham, NC: Duke University Press.

- - 2011. "Disco and the Queering of the Dance Floor". Cultural Studies 25(2): 230-43. <https://doi.org/10.1080/09502386.2011.535989>.

LeBlanc, Larry. 2001. "Indies Thrive on Burgeoning Electronica in Canada as Genre Reaches the Mainstream”. Billboard, 23 June: 78-9.

Luvaas, Brent. 2006. "Re-producing Pop: The Aesthetics of Ambivalence in Contemporary Dance Music". International Journal of Cultural Studies 9(2): 167-87. < https://doi. org/10.1177/1367877906064029>.

Maari, Frédéric. 2009. "De l'organisation au déroulement d'événements rave à Montréal: etude des mécanismes de régulation sociale”. Master's Thesis (Criminology), Université de Montréal.

Madden, David. 2012. "Cross-dressing to Backbeats: The Status of the Electroclash Producer and the Politics of Electronic Music”. Dancecult: Journal of Electronic Dance Music Culture 4(2): 27-47. <https://doi.org/10.12801/1947-5403.2012.04.02.02>.

Marsh, Charity. 2006. “'Understand us before you end us': Regulation,

Governmentality, and the Confessional Practices of Raving Bodies". Popular Music 25(3): 415-30. < https://doi.org/10.1017/s0261143006001000>.

Remiggi, Frank William. 1998. "Le Village gai de Montréal: entre le ghetto et l'espace identitaire”. In Sortir de l'ombre: Histoires des communautés lesbienne et gaie de Montréal, eds. Irène Demczuk and Frank William Remiggi, 269-89. Montréal, QC: VLB Editeur.

Reitsamer, Rosa. 2011. "The DIY Careers of Techno and Drum 'n' Bass DJs in Vienna”. Dancecult: Journal of Electronic Dance Music Culture 3(1): 28-43. < https://doi. org/10.12801/1947-5403.2011.03.01.02>.

Rodgers, Tara. 2010. Pink Noises: Women on Electronic Music and Sound. Durham, NC: Duke University Press.

Straw, Will. 1991. "Systems of Articulation, Logics of Change: Scenes and Communities in Popular Music". Cultural Studies 5(3): 368-88. < https://doi. org/10.1080/09502389100490311>.

- - _ 1993. "The Floor, The Booth and the Wall: Dance Music and the Fear of Falling". Public 8: 169-82. 
- - . 2004. "Cultural Scenes". Society and Leisure 27(2): 411-22. < $\underline{\text { https://doi.org/10.1080/0 }}$ 7053436.2004.10707657>.

- - - 2005. "Pathways of Cultural Movement". In Accounting For Culture: Thinking Through Cultural Citizenship, eds. Caroline Andrew, Monica Gattinger, M. Sharon Jeannotte and Will Straw, 183-97. Ottawa, ON: University of Ottawa Press.

- - . 2008. "Music From the Wrong Place: On the Italianicity of Quebec Disco". Criticism 50(1): 113-32. <https://doi.org/10.1353/crt.0.0054>.

Straw, Will and Douglas Tallack, eds. 2009. Global Cities/Local Sites. Melbourne: Melbourne University Publishing/Universitas 21, U21 e-book.

Stahl, Geoff. 2001. "Tracing out an Anglo-Bohemia: Musicmaking and the Myth of Montreal”. Public 22(23): 99-121. <https://doi.org/10.14361/9783839407967-010>.

Stolarick, Kevin and Richard Florida. 2006. "Creativity, Connections and Innovation: A Study of Linkages in the Montréal Region”. Environment and Planning A. 38(10): 1799-817. $<$ https://doi.org/10.1068/a3874 >

Taylor, Jodie. 2008. “The Queerest of the Queer: Sexuality, Politics and Music on the Brisbane Scene”. Continuum 22(5): 647-61. <https://doi.org/10.1080/10304310802311626>.

_- - 2009. "Spewing Out of the Closet: Musicology on Queer Punk”. In Musical Islands: Exploring Connections Between Music, Place and Research, eds. Elizabeth Mackinlay, Brydie Leigh Bartleet and Katelyn Barney, 221-41. Newcastle: Cambridge Scholars Press.

-_-. 2010. Playing it Queer: Popular Music, Identity and Queer World-making. Bern: Peter Lang.

- - 2012. "Scenes and Sexualities: Queerly Reframing the Music Scenes Perspective". Continuum: Journal of Media \& Cultural Studies 26(1): 143-56. < https://doi.org/10.1080/1 0304312.2011.538471>.

Thornton, Sarah. 1995. Club Cultures: Music, Media and Subcultural Capital. Cambridge: Polity Press.

Turenne, Martin. 2006. "Sliding Down the Surface Electro-clash: Your 15 Minutes Are Up”. Exclaim!, 1 January: < http://exclaim.ca/Features/PointOfView/sliding down surfaceelectro clash_your_15 minutes_are $>$ (accessed 25 February 2016).

Weheliye, Alexander G. 2002. “'Feenin': Posthuman Voices in Contemporary Black

Popular Music". Social Text 20(2): 21-47. < https://doi.org/10.1215/01642472-20-2_71-21>.

Whiteley, Sheila and Jennifer Rycenga, eds. 2006. Queering the Popular Pitch. New York: Routledge.

\section{DISCOGRAPHY}

Adult. 2000. "Nausea”. Nausea. Ersatz Audio (12-inch): EZ-014. <http://www.discogs.com/ADULT-Nausea/release/12616>.

Alter Ego. 2004. "Rocker”. Rocker. Skint Records (12-inch): Skint 103. <http://www.discogs.com/Alter-Ego-Rocker/release/338153>.

Mini. 2006. Audio Hygiene. NRG Komrads (CD): NRGK 001. <http://www.discogs.com/Mini-AudioHygiene/release/827660>. 
Miss Kittin and the Hacker. "Frank Sinatra”. First Album. International Deejay Gigolo Records (CD Album): Gigolo 75. <http://www.discogs.com/Miss-Kittin-e-HackerFirst-Album/release/20345>.

Peaches. 2000. "Fuck the Pain Away". The Teaches of Peaches. Kitty-Yo (CD Album): KY00033CD.

<http://www.discogs.com/Peaches- e-Teaches-Of-Peaches/release/50236>.

Tiga. 2000. Mixed Emotions (Montreal Mix Sessions Vol. 5). Turbo (CD): MARCD-013. <http://www.discogs.com/Tiga-Mixed-Emotions-Montreal-Mix-Sessions-Vol-5/ release $/ 1052>$.

Tiga and Zyntherius. 2001. "Sunglasses at Night". Sunglasses EP. International Deejay GigoloRecords (12-inch): Gigolo 80.

< http://www.discogs.com/Tiga-Zyntherius-Sunglasses-EP/release/18500>. 